\title{
Uji Antiangiogenesis Secara In Vivo Ekstrak Etanol Biji Kopi Robusta (Coffea Robusta) dengan Metode Chorio Allantoic Membrane (CAM)
}

\section{(Antiangiogenesis Test In Vivo Extract of Robusta Coffee Beans (Coffea robusta) Using Chorio Allantoic Membrane (CAM) Method)}

\author{
Muhammad Yusuf $^{1^{*}}$, Rugayyah Alyidrus $^{1}$ \\ ${ }^{*}$ Fakultas Farmasi, Universitas Megarezky, Makassar, Indonesia. \\ E-mail: yusuf.sukarta@gmail.com \\ Article Info: \\ Received: 8 Januari 2020 \\ in revised form: 11 Februari 2020 \\ Accepted: 20 Februari 2020 \\ Available Online: 02 Maret 2020 \\ Keywords: \\ Antiangiogenesis \\ Chorio Allantoic Membrane (CAM) \\ Robusta Coffee Beans (C.Robusta) \\ Corresponding Author: \\ Muhammad Yusuf \\ Fakultas Farmasi \\ Universitas Megarezky \\ Makassar \\ 98220 \\ Indonesia \\ email:yusuf.sukarta@gmail.com

\begin{abstract}
Angiogenesis is a process of forming new capillaries found in the blood vessel system. Angiogenesis plays an important role in tumor growth and metastasis which includes several biological processes. Cancer cells require a supply of nutrients through the blood vessels to grow and develop so that the cancer cells secrete growth substances to stimulate the formation of new blood vessels to meet their nutritional supply. Robusta coffee beans (C. robusta) contain compounds that function as strong antioxidants namely Chlorogenic acid which is a polyphenol group compound that is thought to have antiangiogenesis effects. This study aims to look at the antiangiogenesis potential of robusta coffee bean ethanol extract (C. robusta) with the Chorio Allantoic Membrane (CAM) method and determine the concentration of robusta coffee bean extract (C. robusta) which has the potential as an antiangiogenesis. Antiangiogenesis test using the Chorio Allantoic Membrane (CAM) method using 9-day-old chicken eggs. In this study eggs were divided into 4 groups, group I was the untreated group, groups II, III, IV were groups that were given ethanol extract of robusta coffee beans (C. robusta) with concentrations of $6000 \mu \mathrm{g} / \mathrm{ml}, 5500 \mu \mathrm{g} / \mathrm{ml}$ respectively. and $5000 \mu \mathrm{g} / \mathrm{ml}$. The eggs are re-incubated for 72 hours. In this study, a macroscopic semi-quantitative score was observed. The score data obtained were analyzed statistically by the One Way Anova test. Based on the Saphiro Wilk normality test results, the results of observations of antiangiogenesis in ethanol extracts of Robusta (Coffea robusta) concentrations of $6000 \mu \mathrm{g} / \mathrm{ml}, 5500 \mu \mathrm{g} / \mathrm{ml}$, and $5000 \mu \mathrm{g} / \mathrm{ml}$ obtained a significance value of 0.248 ( $p>0.05$ ). Continuing the One Way Anova test in the antiangiogenesis test obtained a significance value of $0.007(\mathrm{p}<0.05)$. Then proceed with the Post Hoc Test. In the test group the concentration of $6000 \mu \mathrm{g} / \mathrm{ml}, 5500 \mu \mathrm{g} / \mathrm{ml}$, and $5000 \mu \mathrm{g} / \mathrm{ml}$ had a value of $p>0.05$ which means that there were no differences between groups in inhibiting angiogenesis. Based on the results of the study it can be concluded that the ethanol extract of robusta coffee beans (C. robusta) $6000 \mu \mathrm{g} / \mathrm{ml}, 5500 \mu \mathrm{g} / \mathrm{ml}$, and $5000 \mu \mathrm{g} / \mathrm{ml}$ has antiangiogenesis effect on Chorio Allantoic Membrane (CAM) of chicken
\end{abstract} \\ embryo.
}

Copyright $@ 2019$ JFG-UNTAD

This open access article is distributed under a Creative Commons Attribution (CC-BY-NC-SA) 4.0 International license.

How to cite (APA $6^{\text {th }}$ Style):

Yusuf, M., \& Alyidrus, R. (2020). Uji Antiangiogenesis Secara In Vivo Ekstrak Etanol Biji Kopi Robusta (Coffea Robusta) dengan Metode Chorio Allantoic Membrane (CAM). Jurnal Farmasi Galenika :Galenika Journal of Pharmacy (e-Journal), 6(1), 63-69. doi:10.22487/j24428744.2020.v6.i1.14975 


\section{ABSTRAK}

Angiogenesis merupakan proses pembentukan kapiler baru yang terdapat dalam sistem pembuluh darah. Angiogenesis berperan penting dalam pertumbuhan dan metastasis tumor yang meliputi beberapa proses biologis. Sel-sel kanker memerlukan pasokan nutrisi melalui pembuluh darah untuk tumbuh dan berkembang sehingga sel-sel kanker mengeluarkan zat pertumbuhan untuk merangsang pembentukan pembuluh darah baru untuk memenuhi suplai nutrisinya. Biji kopi robusta (C.robusta) mengandung senyawa yang berfungsi sebagai antioksidan kuat yaitu Chlorogenic acid yang merupakan senyawa golongan polifenol yang diduga mempunyai efek antiangiogenesis. Penelitian ini bertujuan untu melihat potensi antiangiogenesis ekstrak etanol biji kopi robusta (C.robusta) dengan metode Chorio Allantoic Membrane (CAM) dan menentukan konsentrasi ekstrak biji kopi robusta (C.robusta) yang berpotensi sebagai antiangiogenesis. Uji antiangiogenesis dengan metode Chorio Allantoic Membrane (CAM) menggunakan telur ayam yang berumur 9 hari. Pada penelitian ini telur dibagi menjadi 4 kelompok, kelompok I adalah kelompok tanpa perlakuan, kelompok II, III, IV merupakan kelompok yang diberi ekstrak etanol biji kopi robusta (C.robusta) dengan masing-masing konsentrasi $6000 \mu \mathrm{g} / \mathrm{ml}, 5500$ $\mu \mathrm{g} / \mathrm{ml}$, dan $5000 \mu \mathrm{g} / \mathrm{ml}$. Telur diinkubasi kembali selama $72 \mathrm{jam}$. Pada penelitian ini dilakukan pengamatan secara macroscopic semiquantitative score. Data skor yang diperoleh dianalisis statistik dengan uji One Way Anova. Berdasarkan hasil uji normalitas Saphiro Wilk data hasil pengamatan antiangiogenesis pada ekstrak etanol biji kopi robusta (Coffea robusta) konsentrasi $6000 \mu \mathrm{g} / \mathrm{ml}, 5500 \mu \mathrm{g} / \mathrm{ml}$, dan $5000 \mu \mathrm{g} / \mathrm{ml}$ diperoleh nilai signifikansi sebesar 0,248 (p>0,05). Dilanjutkan uji One Way Anova pada pengujian antiangiogenesis diperoleh nilai signifikansi sebesar 0,007 ( $<<0,05)$. Kemudian dilanjutkan uji Post Hoc Test. Pada kelompok uji konsentrasi $6000 \mu \mathrm{g} / \mathrm{ml}, 5500 \mu \mathrm{g} / \mathrm{ml}$, dan $5000 \mu \mathrm{g} / \mathrm{ml}$ memiliki nilai $\mathrm{p}>0,05$ yang berarti bahwa tidak ada perbedaan antar kelompok dalam menghambat angiogenesis. Berdasarkan hasil penelitian dapat disimpulkan bahwa ekstrak etanol biji kopi robusta (C. robusta) $6000 \mu \mathrm{g} / \mathrm{ml}, 5500 \mu \mathrm{g} / \mathrm{ml}$, dan $5000 \mu \mathrm{g} / \mathrm{ml}$ memiliki efek antiangiogenesis pada Chorio Allantoic Membrane (CAM) embrio ayam.

Kata kunci: Antiangiogenesis, Chorio Allantoic Membrane (CAM), Biji kopi robusta (C. robusta).

\section{PENDAHULUAN}

Kanker merupakan suatu kondisi pertumbuhan atau pembengkakan massa dari sel yang abnormal dan bersifat ganas. Sel kanker berkembang dengan mengambil nutrisi dan oksigen dari inang (host) dengan cara membentuk pembuluh darah baru (angiogenesis) dari pembuluh darah yang sudah ada. Penghambatan proses angiogenesis dari kanker akan menyebabkan sel kanker mengalami penghambatan pertumbuhan dan akhirnya mati. Angiogenesis diketahui merupakan kunci bagi perkembangan. Angiogenesis merupakan peristiwa pertumbuhan pembuluh darah baru /neovaskularisasi yang memungkinkan sel mendapatkan suplai nutrien dan oksigen, sehingga dapat bertahan hidup (Hanahan \& Weinberg, 2000).

Antiangiogenesis merupakan terapi yang bertujuan untuk menghentikan pembentukan pembuluh darah baru, karena tanpa suplai darah, sel kanker akan mati. Pada uji antiangiogenesis secara in vivo ini menggunakan metode Chorio Allantoic Membrane (CAM) karena vaskularisasi yang luas, mudah dilihat, mudah dijangkau, masa eksperimen lebih cepat, dan diferensiasi pembuluh darah yang baik (Mustafida et al., 2014).

Hal ini mendorong peneliti untuk melakukan uji pendahuluan untuk melakukan pencarian senyawa yang dapat menghambat pertumbuhan sel kanker, dari bahan pangan yang mungkin nantinya dapat berkhasiat sebagai antikanker yang terdapat pada biji kopi robusta (C.robusta). Biji kopi robusta (C.robusta) mengandung senyawa yang berfungsi sebagai antioksidan. Senyawa di dalam kopi robusta (C.robusta) yang bertindak sebagai antioksidan kuat adalah Chlorogenic acid yang merupakan senyawa golongan polifenol (Gaascht et al., 2015).

Berdasarkan beberapa penelitian menujukkan bahwa kopi juga memiliki aktivitas sebagai antikanker. Pada penelitian tersebut disebutkan bahwa Cafestol dan Kahweol yang merupakan zat yang terkandung di dalam kopi ini secara spesifik memiliki aktivitas antikarsinogenik (Cavin et al., 2002). 
Penelitian lain juga menunjukkan bahwa potensi kopi sebagai antikanker ditunjukan dengan cara meningkatkan aktivitas enzim fase II, akan tetapi belum diketahui dengan pasti seberapa banyak minuman kopi yang diperlukan agar berefek sebagai pelindung tubuh dari serangan kanker. Dr. Thomas Hofmann, prof dr Institute for Food Chemistry at the University of Manchester di Jerman menyebutkan bahwa kopi espresso mengandung 2-3 kali lebih banyak komponen antikanker (Winarsi, 2007).

Berdasarkan uraian tersebut, untuk mengoptimalkan pemanfaatan biji kopi robusta (C.robusta) sebagai sumber bahan obat maka peneliti berencana melakukan uji antiangiogenesis secara in vivo ekstrak biji kopi robusta (C.robusta) dengan metode Chorio Allantoic Membrane (CAM) dengan menggunakan telur.

\section{METODE PENELITIAN}

\section{Alat dan Bahan}

Alat yang digunakan pada penelitian ini adalah alat-alat gelas (pyrex), gunting, Laminar Air Flow (LAF), Minidrill, Timbangan analitik, Rotavapor, seperangkat alat maserasi, seperangkat alat penetasan, inkubator, spoit, Termometer, Timbangan $O$ 'haus dan Vial. Bahan yang digunakan pada penelitian ini yaitu Aquadest, Ekstrak etanol biji kopi robusta (C.robusta), Etanol $70 \%$, Na-CMC, Parafin, Paper disc, telur ayam kampung.

\section{Metode}

Metode yang digunakan dalam penelitian ini adalah ekperimental laboratorium dengan metode Chorio Allantoic Membrane (CAM).

\section{Pengambilan dan Pengolahan Sampel}

Sampel biji kopi robusta diperoleh dari kab. Toraja, lalu dibuat menjadi ekstrak biji kopi. Pembuatan ekstrak biji kopi ini dilakukan dengan cara maserasi dengan proses sebagai berikut; Biji kopi dijadikan serbuk dengan mesin penyerbuk. Serbuk biji kopi yang didapatkan dilarutkan dengan etanol $70 \%$ sebanyak 7 liter, diaduk selama 30 menit, didiamkan selama 24 jam, kemudian disaring. Proses ini diulang 3 kali. Kemudian di peroleh hasil berupa ampas dan filtrat. Ampas dibuang, sedangkan filtrat diuapkan dengan vacum rotary evaporator. Ekstrak kental yang didapatkan dituang dalam cawan porselin, lalu dipanaskan dalam water bath sambil terus diaduk sampai diperoleh ekstrak biji kopi.

\section{Pemilihan sampel uji}

Sampel uji yang digunakan adalah telur ayam kampung yang berumur 1 hari.

\section{Pengujian Antiangiogenesis}

Telur ayam diinkubasikan terlebih dahulu selama 9 hari dan kemudian diberikan perlakuan. Tahap awal perlakuan dengan proses candling untuk melihat udara yang ada didalam telur kemudian memberi tanda pada kerabang telur di daerah yang akan dibuat segi empat (jendela) berukuran $1 \mathrm{x} 1 \mathrm{~cm}$ di atas embrio. Kerabang telur disucihamakan dengan alkohol. Selanjutnya pada kedua daerah tersebut dibuat lubang kecil menggunakan sebuah mini drill. Kerabang telur di atas embrio dipotong dengan gergaji (mini drill) didalam Laminar Air Flow (LAF) untuk membuat lubang segi empat dengan luas $1 \times 1 \mathrm{~cm}$. Melalui lubang ini sampel uji diimplantasi ke dalam membran korio alantois yang telah terbentuk. Subyek uji berupa telur dibagi dalam empat kelompok (masing- masing kelompok terdir dari 5 butir telur). Kelompok I kelompok tanpa perlakuan, kelompok II kelompok kontrol paper disc bermuati ekstrak etanol biji kopi robusta (C.robusta) dengan konsentrasi $6000 \mu \mathrm{g} / \mathrm{ml}$, kelompok III kelompok kontrol paper disc bermuati ekstrak etanol biji kopi robusta (C.robusta) dengan konsentrasi $5500 \mu \mathrm{g} / \mathrm{ml}$, dan kelompok IV kelompok kontrol paper disc bermuati ekstrak etanol biji kopi robusta (C.robusta) dengan konsentrasi $5000 \mu \mathrm{g} / \mathrm{ml}$. Setelah diberi perlakuan, tutup pintu pada telur dengan 
segera dan hati-hati. Kemudian segel pintu tersebut dengan parafin solidium, telur diinkubasi pada suhu $37^{\circ} \mathrm{C}$ selama 3 hari atau $72 \mathrm{jam}$, kemudian telur dibuka pada umur 12 hari secara vertikal kemudian dilakukan pengamatan secara makroskopis dan pendokumentasian membran chorio allantoic yang berada di atas paper disc (Mustafida et al, 2014).

\section{HASIL DAN PEMBAHASAN}

Hasil pengujian ekstrak etanol biji kopi robusta (Coffea robusta) berdasarkan pemberian skor pada uji antiangiogenesis menggunakan metode Chorio Allantoic Membrane (CAM) dapat dilihat pada tabel berikut.

Tabel 1. Hasil skor uji Antiangiogenesis ekstrak etanol biji kopi robusta (Coffea robusta)

\begin{tabular}{cccccc}
\hline Kelompok & T1 & T2 & T3 & T4 & T5 \\
\hline K1 & 5 & 5 & 4 & 5 & 4 \\
K2 & 2 & 0 & 2 & 3 & 2 \\
K3 & 3 & 4 & 3 & 3 & 4 \\
K4 & 4 & 3 & 4 & 4 & 3 \\
\hline
\end{tabular}

Keterangan :

K1 : Kelompok tanpa perlakuan

$\mathrm{K} 2$ : Kelompok ekstrak etanol biji kopi robusta $(6000 \mu \mathrm{g} / \mathrm{ml})$

$\mathrm{K} 3$ : Kelompok ekstrak etanol biji kopi robusta $(5500 \mu \mathrm{g} / \mathrm{ml})$

K4 : Kelompok ekstrak etanol biji kopi robusta $(5000 \mu \mathrm{g} / \mathrm{ml})$

T1 : Telur 1

T2 : Telur 2

T3 : Telur 3

T4 : Telur 4

T5 : Telur 5

Tabel 2. Hasil Rerata uji Antiangiogenesis ekstrak etanol biji kopi robusta (Coffea robusta)

\begin{tabular}{ccc}
\hline Kelompok & $\mathbf{N}$ & Hasil uji antiangiogenesis $($ mean \pm SD) \\
\hline K1 & 5 & $4,6 \pm 0,577$ \\
K2 & 5 & $1,8 \pm 0,577$ \\
K3 & 5 & $3,4 \pm 0,577$ \\
K4 & 5 & $3,6 \pm 0,577$ \\
\hline
\end{tabular}

Keterangan :

K1 : Kelompok tanpa perlakuan

$\mathrm{K} 2$ : Kelompok ekstrak etanol biji kopi robusta $(6000 \mu \mathrm{g} / \mathrm{ml})$

K3 : Kelompok ekstrak etanol biji kopi robusta $(5500 \mu \mathrm{g} / \mathrm{ml})$

K4 : Kelompok ekstrak etanol biji kopi robusta $(5000 \mu \mathrm{g} / \mathrm{ml})$ 
Untuk hasil pengujian ekstrak etanol biji kopi robusta (Coffea robusta) menggunakan metode Chorio Allantoic Membrane (CAM) dapat dilihat pada gambar berikut ini :

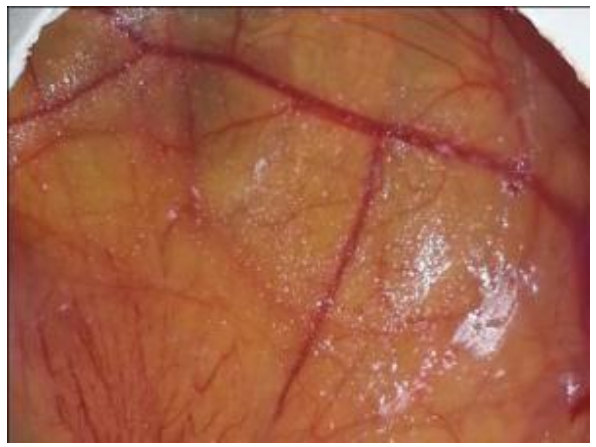

Gambar 1. Kontrol tanpa perlakuan pada telur ayam

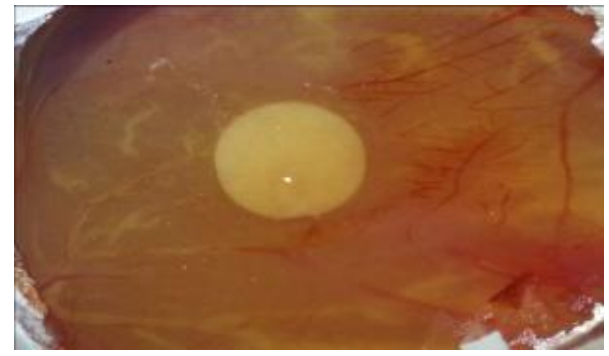

Gambar 2. Kontrol perlakuan dengan ekstrak etanol biji kopi robusta konsentrasi $6000 \mu \mathrm{g} / \mathrm{ml}$ pada telur ayam

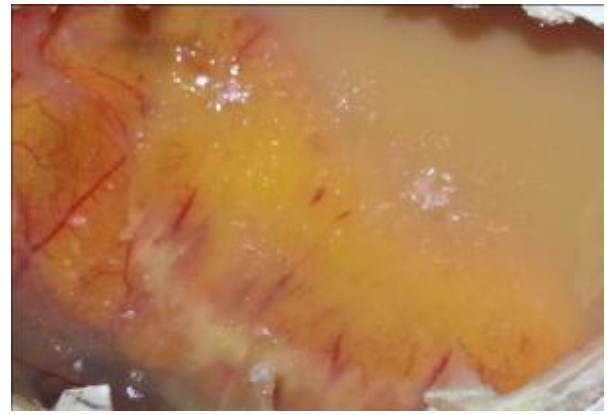

Gambar 3. Kontrol perlakuan dengan ekstrak etanol biji kopi robusta konsentrasi $5500 \mu \mathrm{g} / \mathrm{ml}$ pada telur ayam

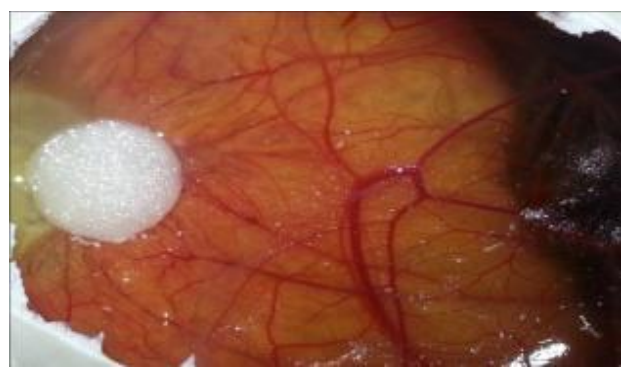

Gambar 4. Kontrol perlakuan dengan ekstrak etanol biji kopi robusta konsentrasi $5000 \mu \mathrm{g} / \mathrm{ml}$ pada telur ayam

Berdasarkan hasil pengamatan secara macroscopic semiquantitative score, pada uji antiangiogenesis dapat dilihat pada tabel 1 dan hasil rerata uji antiangiogenesis dapat dilihat pada tabel 2. Pada kelompok 1 yaitu kelompok telur tanpa diberi perlakuan diperoleh nilai rerata skor 4,6 karena pada kelompok ini tidak terjadi penghambatan pertumbuhan pembuluh darah.pada kelompok 2 yaitu telur 
yang diberi ekstrak dengan kosentrasi $6000 \mu \mathrm{g} / \mathrm{ml}$ diperoleh rerata skor 1,8 karena dapat terlihat dengan jelas bahwa pembuluh darah yang tumbuh atau berkembang terhambat oleh adanya ekstrak etanol biji kopi robusta (Coffea robusta), pembuluh darah terpotong atau terpisah menjadi beberapa bagian, pada kelompok 3 yaitu telur yang diberi ekstrak dengan konsentrasi $5500 \mu \mathrm{g} / \mathrm{ml}$ diperoleh nilai rerata skor 3,4 karena jumlah pembuluh darah sudah mulai berkurang. Pada kelompok 4 yaitu telur yang diberi ekstrak konsentrasi $5000 \mu \mathrm{g} / \mathrm{ml}$ diperoleh nilai rerata skor 3,6 karena jumlah pembuluh darahnya masih banyak. Berdasarkan hasil penelitian tersebut menunjukkan bahwa semakin besar jumlah konsentrasi ekstrak etanol biji kopi robusta (Coffea robusta) yang dimasukkan, maka semakin berkurang jumlah pembuluh darah yang tumbuh dan nilai skor semakin rendah.

Berdasarkan hasil uji normalitas Saphiro Wilk data hasil pengamatan antiangiogenesis pada ekstrak etanol biji kopi robusta (Coffea robusta) konsentrasi $6000 \mu \mathrm{g} / \mathrm{ml}, 5500 \mu \mathrm{g} / \mathrm{ml}$, dan $5000 \mu \mathrm{g} / \mathrm{ml}$ diperoleh nilai signifikansi sebesar 0,248 yang berarti data terdistribusi normal ( $>0,05)$. Dilanjutkan uji statistik One Way Anova pada pengujian antiangiogenesis diperoleh nilai signifikansi sebesar 0,007 $(\mathrm{p}<0,05)$ yang berarti bahwa terdapat perbedaan nilai rerata antar kelompok. Kemudian dilanjutkan uji Post Hoc Test untuk melihat perbedaan rerata dari tiap kelompok. Pada kelompok uji konsentrasi 6000 $\mu \mathrm{g} / \mathrm{ml}, 5500 \mu \mathrm{g} / \mathrm{ml}$, dan $5000 \mu \mathrm{g} / \mathrm{ml}$ memiliki nilai $\mathrm{p}>0,05$ yang berarti bahwa tidak ada perbedaan antar kelompok dalam menghambat angiogenesis yang menandakan bahwa ekstrak etanol biji kopi robusta (Coffea robusta) dapat menghambat proses angiogenesis pada Chorio Allantoic Membrane (CAM). Penghambatan angiogenesis oleh ekstrak ini diasumsikan disebabkan oleh kandungan kimia yang berada pada biji kopi robusta (Coffea robusta) yaitu senyawa Chlorogenic acid dan juga Caffeine. Senyawa Caffeine pada biji kopi memiliki aktivitas antiangiogenesis secara in vivo dan juga dapat menghambat proliferasi sel dan juga dapat mengiduksi apoptosis dengan memodulasi caspase-3 dan Bcl-2 (Li et al., 2013; Yeh et al., 2012).

Chlorogenic acid yang terdapat pada biji kopi dilaporkan juga dapat menghambat laser-induced neovascularization (CNV) pada model tikus, dan juga senyawa p-coumaric acid yang merupakan suatu senyawa konstituen fenolik dari Chlorogenic acid yang dilepaskan selama katabolisme dapat menghambat pertumbuhan dan migrasi sel-sel endotel, dan juga mengurangi sekresi growth factor (FGF, VEGF) pada tingkat mRNA yang bekerja pada jalur Akt dan Erk (Kong et al., 2013).

Mekanisme penghambatan angiogenesis oleh ekstrak etanol biji kopi robusta (Coffea robusta) pada Chorio Allantoic Membrane (CAM) belum dapat dipastikan, karena diduga dengan cara menghambat Vascular endhotelial growth factor (VEGF). Walaupun demikian penelitian ini belum bisa menjelaskan senyawa bioaktif mana pada biji kopi robusta (Coffea robusta) yang bersifat antiangiogenik (Gaascht et al., 2015).

Dalam hal ini dapat dilihat bahwa pada penelitian tersebut ekstrak etanol biji kopi robusta (Coffea robusta) dapat memberikan efek antiangiogenesis serta bersifat toksik pada konsentrasi $6000 \mu \mathrm{g} / \mathrm{ml}$, $5500 \mu \mathrm{g} / \mathrm{ml}$, dan $5000 \mu \mathrm{g} / \mathrm{ml}$. Hal ini menunjukkan bahwa ekstrak etanol biji kopi robusta (Coffea robusta) dapat berpotensi sebagai antikanker.

\section{KESIMPULAN}

Berdasarkan hasil penelitian dapat disimpulkan bahwa ekstrak etanol biji kopi robusta (Coffea robusta) memiliki efek antiangiogenesis pada Chorio Allantoic Membrane (CAM) pada embrio ayam, dan ekstrak etanol biji kopi robusta (Coffea robusta) memiliki efek antiangiogenesis pada konsentrasi $6000 \mu \mathrm{g} / \mathrm{ml}, 5500 \mu \mathrm{g} / \mathrm{ml}$, dan $5000 \mu \mathrm{g} / \mathrm{ml}$. Adapun saran dari penelitian ini agar pada penelitian selanjutnya menggunakan konsentrasi yang lebih variatif dengan jumlah yang lebih besar dan perlu dilakukan penelitian lebih lanjut mengenai uji zat aktif ekstrak etanol biji kopi robusta (Coffea robusta) yang berperan pada mekanisme penghambatan angiogenesis. 


\section{UCAPAN TERIMAKASIH}

Kami mengucapkan terima kasih yang sebesar-besarnya kepada para dosen program studi S1 Farmasi Universitas Megarezky atas masukan dan arahan dalam proses penelitian ini sehingga dapat terselesaikan. Ucapan terima kasih juga kami ucapkan kepada Kementerian Riset, Teknologi dan Pendidikan Tinggi karena telah membiayai keseluruhan dalam penelitian ini.

\section{DAFTAR PUSTAKA}

Cavin, C., Holzhaeuser, D., Scharf, G., Constable, A., Huber, W. W., \& Schilter, B. (2002). Cafestol and kahweol, two coffee specific diterpenes with anticarcinogenic activity. Food and Chemical Toxicology, 40(8), 1155-1163.

Gaascht, F., Dicato, M., Diederich, M. (2015). Coffee provides a natural multitarget pharmacopeia against the hallmarks of cancer. Genes Nutr, 10:51. Pp 1-17. doi: 10.1007/s12263-015-0501-3

Hanaahan, D., \& Weinberg. 2000. The Hallmark of Cancer. Cell, Vol. 100, 50-70. DOI:https://doi.org/10.1016/S0092-8674(00)81683-9.

Kong, C. S., Jeong, C. H., Choi, J. S., Kim, K. J., Jeong, J. W. (2013) Antiangiogenic effects of pcoumaric acid in human endothelial. Cells Phytother Res, 27:317-323. doi:10.1002/ptr.4718

Li, H., Jin, S. Y., Son, H. J., Seo, J. H., Jeong, G. B. (2013) Caffeine-induced endothelial cell death and the inhibition of angiogenesis. Anat Cell Biol 46:57-67. doi:10.5115/acb.2013.46.1.57

Mustafida, Y, R., Munawir, A. L., Dewi, R. (2014), Efek Antiangiogenik Ekstrak Etanol Mahkota Dewa (Phaleria Macropa (Scheff).Boerl.) pada Membran Kolorioalantois (CAM) Embrio Ayam, E-jurnal Pustaka Kesehatan, 2:5.

Winarsi, H. (2007). Antioksidan dan Radikal Bebas Potensi dan Aplikasinya dalam Kesehatan. Yogyakarta: Kanisius.

Yeh, C. H., Liao, Y. F., Chang, C. Y., Tsai, J. N., Wang, Y. H., Cheng, C. C., ... \& Chen, Y. H. (2012). Caffeine treatment disturbs the angiogenesis of zebrafish embryos. Drug and chemical toxicology, 35(4), 361-365. 